\title{
Concentrations of Plasma Luteinizing Hormone in Infants, Children, and Adolescents with Normal and Abnormal Gonadal Function
}

\author{
Allen W. Root ${ }^{[71]}$, Thomas Moshang, Jr., Alfred M. Bongiovanni and Walter R. Eberlein \\ Division of Endocrinology, The Children's Hospital of Philadelphia, \\ and Department of Pediatrics, University of Pennsylvania School of Medicine, Philadelphia, Pennsylvania, USA
}

\section{Extract}

This communication reports the development of a sensitive, reproducible, and specific radioimmunoassay for luteinizing hormone (LH) in plasma and the application of this method to a cross-sectional survey of plasma LH concentrations in 243 infants, children, and adolescents with normal and abnormal growth and sexual development. One nanogram of Hartree purified human pituitary LH standard was immunologically equivalent to $13.7 \mathrm{mIU}$ of the Second International Reference Preparation of Human Menopausal Gonadotropin. The lower limit of sensitivity of the assay varied between 0.025 and $0.05 \mathrm{ng} / \mathrm{ml}$. Specimens of plasma containing $<0.25 \mathrm{ng} / \mathrm{ml}(<3.7 \mathrm{mIU} / \mathrm{ml})$ have been considered indistinguishable from 'zero'.

Plasma LH concentrations increased after 9 years of age in normal boys and after 6 years of age in normal girls. In males with constitutional delay in growth and development, LH levels were generally lower than in normal boys of comparable ages (figs. 3 and 4). The plasma LH concentration also increased with advancing sexual maturation (fig. 5).

Levels of LH were $<0.25 \mathrm{ng} / \mathrm{ml}$ in 15 of 18 males (6-20 years old) and in 10 of 11 females (6-19 years old) with hypopituitarism and documented lack of human growth hormone response to hypoglycemia. In three such patients, plasma LH concentrations correlated with their degrees of sexual maturation, but in a 16-year-old clinically prepubertal male, patient $S A$, with hypopituitarism secondary to a craniopharyngioma, LH levels higher than normal male values were noted.

Plasma LH concentrations were 1.2 and $1.45 \mathrm{ng} / \mathrm{ml}$ in 2 of 3 girls less than 4 years old, with gonadal dysgenesis, and ranged between 0.33 and $3.6 \mathrm{ng} / \mathrm{ml}$ in 10 of 15 older patients with this diagnosis (table III). The plasma LH concentration was $1.7 \mathrm{ng} / \mathrm{ml}$ in a 3-month-old male pseudohermaphrodite. Plasma LH concentrations ranged between 0.38 and $0.88 \mathrm{ng} / \mathrm{ml}$ in five of seven children with true sexual precocity. In 13 of 15 girls with precocious thelarche, and in all of 10 patients with premature pubarche, LH levels were $<0.25 \mathrm{ng} / \mathrm{ml}$. The intravenous infusion of conjugated equine estrogens was followed by a prompt decline in plasma LH levels in patients with gonadal dysgenesis and Klinefelter's syndrome, but failed to alter significantly LH values in patient $S A$ (fig. $6 A, B, C$ ). Administration of clomiphene citrate and cisclomiphene citrate increased plasma LH concentrations in normal males, but failed to do so in patients with hypopituitarism, including patient $S A$ (fig. $7 A, B$ ). The intramuscular administration of medroxyprogesterone acetate was associated with suppression of plasma LH levels in two patients with true sexual precocity (fig.8). 
Speculation

The hypothalamic-pituitary-gonadal axis is active in the prepubertal human subject, and is responsive to abnormal function in one segment of the system.

\section{Introduction}

Since the development of the radioimmunoassay for plasma insulin by YALOw and Berson [50], these techniques have been applied to the measurement of many other protein and polypeptide hormones [4, 28, 35, 47]. Recently, radioimmunoassays for the measurement of follicle-stimulating hormone ( $\mathrm{FSH})$ and luteinizing hormone ( $\mathrm{LH})$ have been developed and utilized for the investigation of gonadotropic function in adults $[3,7,10,11,23,24,27,38,39,41-43,45,46]$, and several investigators have also applied these methods to the study of gonadotropin concentrations in the sera of children [1, 10, 15, 19, 20, 27, 34, 39, 40, 45, 53]. We are reporting our experience with a specific, precise, and sensitive radioimmunoassay for $\mathrm{LH}$ and the results of a cross-sectional survey of plasma LH concentrations in 243 infants, children, and adolescents with normal and abnormal growth and sexual maturation.

\section{Materials and Methods}

\section{Radioimmunoassay of LH [33]}

The antigenic similarity between pituitary $\mathrm{LH}$ and placental human chorionic gonadotropin (HCG) has been documented $[6,29,48]$. Antisera to $H G G$ were prepared in guinea pigs by the subcutaneous administration fortnightly of 3,000 IU of HCG [54] dissolved in $1 \mathrm{ml}$ of saline and emulsified in $1 \mathrm{ml}$ of complete Freund's adjuvant [55]. Serum was harvested by cardiac puncture after the fifth injection and stored at $-20^{\circ}$. The antiserum selected for use in the assay was that which exhibited the greatest degree of dissociation from tracer $\mathrm{LH}^{-131} \mathrm{I}$ with the smallest quantity of unlabeled LH [5]. Hartree human pituitary LH [56] was labeled with ${ }^{131} \mathrm{I}[12,27,57]$ to specific activities of 250-500 $\mu \mathrm{Ci} / \mu \mathrm{g}$. Hartree LH also was used as standard in the assay. It was compared immunologically with the Second International Reference Preparation of Human Menopausal Gonadotropin (2nd IRP-HMG) [58] and to LER 907, the gonadotropin reference standard recently distributed by the National Pituitary Agency [59].

The radioimmunoassay was performed in disposable glass test tubes ( $10 \mathrm{~mm}$ by $75 \mathrm{~mm}$ ) to which were added : $0.5 \mathrm{ml}$ of diluent [60] or Hartree LH standard in diluent $(0.025-2.5 \mathrm{ng} / \mathrm{ml}) ; 0.1 \mathrm{ml}$ of unknown plasma or plasma from a patient with hypopituitarism; 0.1 $\mathrm{ml}$ of LH-131 I (approximately $0.05-0.1 \mathrm{ng}, 15-20,000$ $\mathrm{cpm}$ ); and $0.1 \mathrm{ml}$ of guinea pig anti-HCG serum $(1: 80,000)$. Tubes for the determination of total radioactive counts added and of nonspecifically precipitated counts were also prepared. After incubation for $96 \mathrm{~h}$ at $4^{\circ}, 0.1 \mathrm{ml}$ of normal guinea pig serum $(1: 200)$ in $0.1 \mathrm{~m}$ sodium ethylenediaminetetraacetate (EDTA) and $0.1 \mathrm{ml}$ of rabbit anti-guinea pig gamma globulin $(1: 2)$ were added. The incubation was continued for $72 \mathrm{~h}$ at $4^{\circ}$. On day 8 , the tubes were transferred directly from the refrigerator to precooled centrifuge cups and centrifuged for $30 \mathrm{~min}$, at 3,000 rpm and $4^{\circ}$. The supernatant was discarded and the precipitated (antibodybound) $\mathrm{LH}-{ }^{131} \mathbf{I}$ was counted in an automatic gamma spectrometer [61] employing a background subtract correction for the nonspecifically precipitated counts. More than $90 \%$ of $\mathrm{LH}^{-131}$ I was precipitable by excess anti-HCG serum in the absence of unlabeled LH.

The standard curve was constructed by plotting the percentage of antibody-bound $\mathrm{LH}_{-}{ }^{131} \mathrm{I}$ against the standard concentrations of $\mathrm{LH}$. The $\mathrm{LH}$ content of an unknown specimen was determined directly from the standard curve and expressed in nanograms of Hartree LH per milliliter of undiluted plasma. All standards and unknown specimens were analyzed in triplicate. Longitudinal study specimens were analyzed in the same assay to minimize interassay variability.

\section{Subjects}

Blood was drawn in heparinized syringes and the plasma stored at $-20^{\circ}$. Specimens were obtained randomly from the following types of subjects:

Normal males $(\mathrm{N}=61), 1$ month -19 years of age, without evidence of disease of the central nervous system or of the pituitary-testicular axis; males with constitutional delay in growth and development [49] $(\mathrm{N}=44), 6-16$ years of age; normal females $(\mathrm{N}=48)$, 2 months-15 years of age; all were premenarchal and without evidence of disease of the central nervous system or of the pituitary-ovarian axis; patients with hypopituitarism and documented lack of growth hormone response to hypoglycemia [35] ( $N=29), 6-20$ years of age; phenotypic females with gonadal dysgenesis $(\mathrm{N}=18), 3$ weeks -18 years of age; anorchic males $(\mathrm{N}=6), 11-22$ years of age; male pseudohermaphrodites $(\mathrm{N}=5), 3$ months-15 years of age; and subjects with precocious sexual development $(\mathrm{N}=32)$, 1-11 years of age. 
Plasma LH concentrations were also determined in seven normal adult males, five males with Klinefelter's syndrome and three subjects with XYY sex chromosome constitution. Informed consent was obtained [68].

\section{Special Studies}

The effect of intravenously administered conjugated equine estrogens [62] upon plasma LH levels was determined in subjects with gonadal dysgenesis, Klinefelter's syndrome, and hypopituitarism. Glomiphene citrate and cisclomiphene citrate [63] were administered orally to three normal adult males and to five males with hypopituitarism, and the effect on plasma $\mathrm{LH}$ concentrations studied. The plasma LH response to the intramuscular administration of medroxyprogesterone acetate was investigated in two patients with true sexual precocity.

\section{Results}

\section{Radioimmunoassay of $\mathrm{LH}$}

Figure 1 presents a representative standard curve for Hartree LH and for the 2nd IRP-HMG. A similar curve was obtained when HCG or LER 907 served as standard. One nanogram of Hartree LH was equivalent immunologically to $13.7 \mathrm{mIU}$ of the 2nd IRPHMG and to $100 \mathrm{ng}$ of LER 907. The immunological potency of Hartree LH relative to the 2nd IRP-HMG was derived from 22 assays utilizing data between 'zero' and $1.0 \mathrm{ng} / \mathrm{ml}$ Hartree $\mathrm{LH}$ and 'zero' and 10.0 $\mathrm{mIU} / \mathrm{ml}$ 2nd IRP-HMG. The range of potencies in these assays was 11.8-16.6 mIU/ng (sD 1.3). This immunologic potency is higher than that reported by ODELL et al. [27] for a similar Hartree pituitary LH preparation. The authors have no explanation for this discrepancy. Hypopituitary plasma from three patients significantly increased the binding of LH-131I by antiHCG serum (fig. 2, table I) and was, therefore, added to all tubes containing standard Hartree $\mathrm{LH}$ as indicated in Methods. This phenomenon was not due to the salt content of the plasma, inasmuch as the effect was not altered by dialysis of the plasma. A similar effect has been noted with horse serum [45]. Human growth hormone [64], porcine adrenocorticotropin [65], porcine insulin [66], and plasma from patients with primary hypothyroidism, presumably containing high levels of thyrotropin, did not displace LH-131Y from the anti-HCG serum utilized, as reported previously [33]. Anti-HCG serum bound insignificant amounts $(<1 \%)$ of HFSH-131I (LER-869-2) [59].

The lower limit of sensitivity of the standard curve varied between 0.025 and $0.05 \mathrm{ng} / \mathrm{ml}$. Plasma specimens containing $<0.25 \mathrm{ng} / \mathrm{ml}$ of $\mathrm{LH}$ have been con-

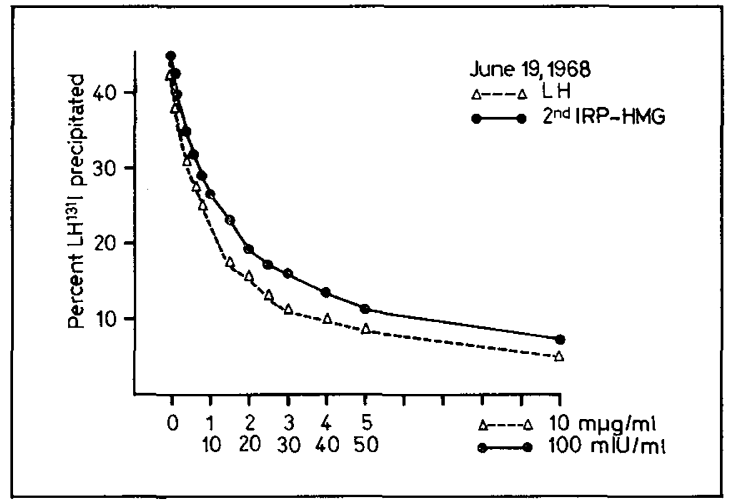

Fig. 1. Standard curves for Hartree pituitary LH and for the Second International Reference Preparation of Human Menopausal Gonadotropin (2nd IRPHMG).

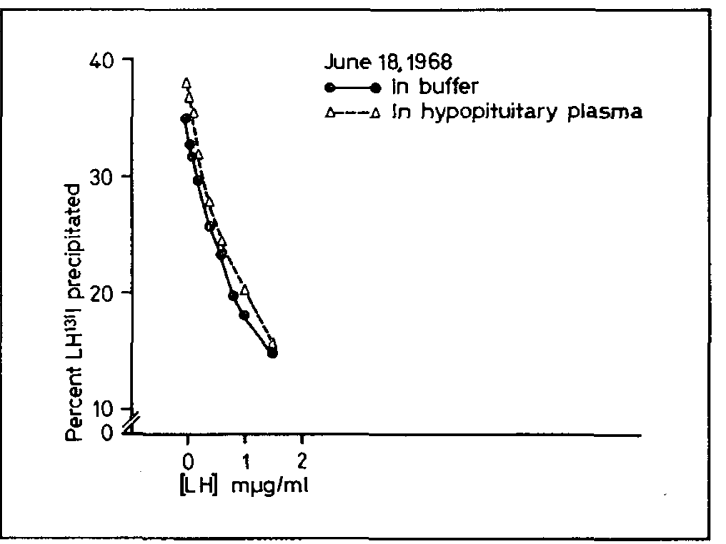

Fig. 2. Effect of plasma from a subject with hypopituitarism upon the standard curve for Hartree LH.

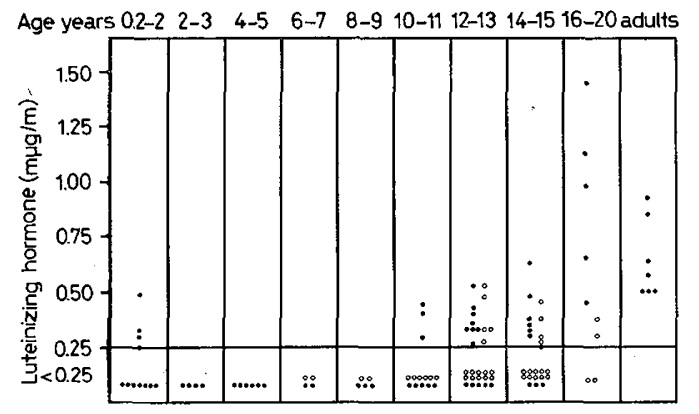

Fig. 3. Plasma LH concentrations in normal males $(\bullet)$ and in males with constitutional delay in growth and development (O). (One nanogram Hartree LH immunologically equivalent to $13.7 \mathrm{mIU}$ of $2 \mathrm{nd}$ IRP-HMG and $100 \mathrm{ng}$ LER 907.) 
sidered indistinguishable from 'zero'. The mean LH concentration of a plasma specimen from one adult male determined 12 times in the same assay, was 0.90 $\mathrm{ng} / \mathrm{ml}$ (sD 0.09), while the mean concentration of this specimen measured in 8 consecutive assays was 0.94 $\mathrm{ng} / \mathrm{ml}$ (sD 0.06). Approximately 90\% (70-116\%) of pituitary LH added to hypopituitary plasma at concentrations between 0.25 and $8.0 \mathrm{ng} / \mathrm{ml}$ was recovered. Assay of varying volumes (up to $0.1 \mathrm{ml}$ ) of plasma containing a high concentration of $\mathrm{LH}$ did not alter the calculated LH corcentration of the specimen. Table II

Table I. Effect of plasma from a subject with hypopituitarism upon the binding of $\mathrm{LH}^{-131} \mathrm{I}$ by anti-HCG

\begin{tabular}{lcc}
\hline \multicolumn{3}{c}{ Percentage binding of $\mathrm{LH}^{-131}$ I to anti-HCG } \\
\cline { 2 - 3 } & $\begin{array}{c}\text { Without plasma } \\
(20)^{1}\end{array}$ & $\begin{array}{c}\text { With plasma } \\
(19)^{1}\end{array}$ \\
\hline Mean & 27.5 & $30.7^{2}$ \\
SD & 0.9 & 0.6 \\
\hline
\end{tabular}

1 Numbers in parentheses indicate number of tests. ${ }^{2} t=22.2442 ; P<0.005$.

Table II. Correlation between radioimmunoassay and bioassay of gonadotropin preparations

\begin{tabular}{lccc}
\hline $\begin{array}{l}\text { Prepara- } \\
\text { tion }\end{array}$ & FSH/LH $\begin{array}{c}\text { Radio- } \\
\text { immuno- } \\
\text { assay }\end{array}$ & $\begin{array}{c}\text { Bio- } \\
\text { assay }\end{array}$ & $\begin{array}{c}\text { Index of } \\
\text { discrimina- } \\
\text { tion, immu- } \\
\text { nopotency/ } \\
\text { biopotency }\end{array}$ \\
\hline
\end{tabular}

\begin{tabular}{rllll}
\hline Urinary & & & & \\
PR2101 & 0.59 & $0.783^{1}$ & $1.7^{1}$ & 0.5 \\
PR2128 & 0.89 & $0.997^{1}$ & $1.1^{1}$ & 0.9 \\
PR2075 & 0.9 & $0.998^{1}$ & $1.1^{1}$ & 0.9 \\
PR2119 & 2.9 & $0.093^{1}$ & $0.35^{1}$ & 0.3 \\
PR2167 & 50.0 & $0.748^{1}$ & $0.60^{1}$ & 1.2 \\
Pituitary & & & & \\
LER907 & 0.4 & $28.0^{2}$ & $48.0^{2}$ & 0.6 \\
\hline
\end{tabular}

${ }^{1}$ Luteinizing hormone, international units of 2 nd International Reference Preparation Human Menopausal Gonadotropin (2nd IRP-HMG) per milliliter.

${ }^{2}$ Luteinizing hormone, international units of 2 nd IRP-HMG per milligram. (Preparations and bioassay of Cutter Laboratories, Berkeley, California, supplied by Dr. G.T. Ross, National Cancer Institute, National Institutes of Health.) indicates that a relatively good correlation existed between levels of $\mathrm{LH}$ determined by bioassay and by radioimmunoassay for several urinary gonadotropin preparations with varying $\mathrm{FSH} / \mathrm{LH}$ ratios. High $\mathrm{FSH}$ levels did not seem to interfere with the LH assay.

\section{Plasma LH Concentrations}

Normal subjects. Figure 3 presents the plasma LH concentrations recorded in normal males and in boys with constitutional delay in growth and development. Generally, the plasma LH level tended to increase after 9 years of age, although 4 of 11 infant boys had measurable plasma LH. In males with constitutional delay in growth and development, $\mathrm{LH}$ concentrations were usually lower (i.e., were undetectable in a relatively greater number of subjects) than in normal boys. Figure 4 presents similar data obtained in normal girls, all of whom were premenarchal. Concentrations of $\mathrm{LH}$ increased after 6 years of age in this group. No infant girl had measurable levels of LH. Fifty-four boys and

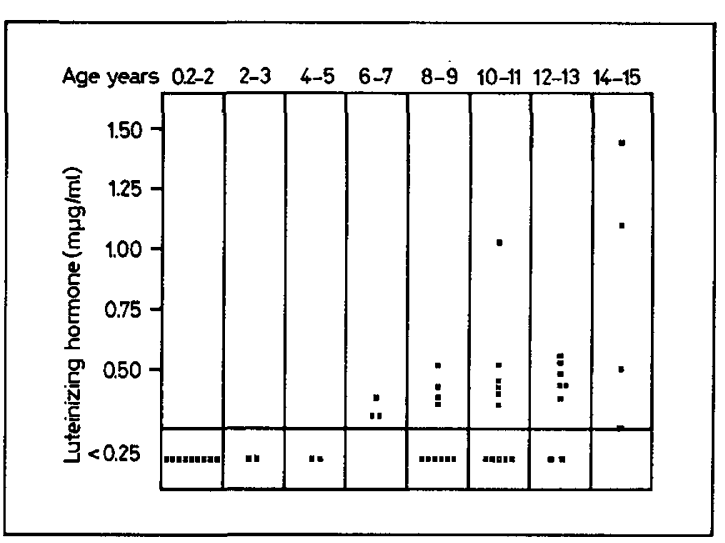

Fig.4. Plasma LH concentrations in normal premenarchal females.

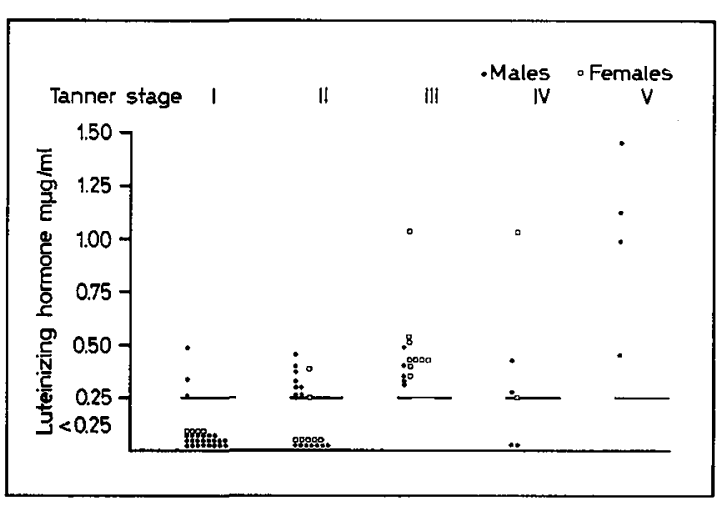

Fig.5. Relation of the stage of sexual maturation to the plasma LH concentration in males $(\bullet)$ and premenarchal females ( $\square$ ). 
21 girls were classified by the criteria of TANNER [44] into five stages of sexual maturation. Figure 5 indicates that increasing concentrations of $\mathrm{LH}$ in plasma were recorded with advancing stages of sexual development in both sexes, but that even in some subjects with significant sexual maturation plasma $\mathrm{LH}$ concentrations were below the limit of sensitivity of the present assay.

Hypopituitarism. Concentrations of $\mathrm{LH}$ were $<0.25$ $\mathrm{ng} / \mathrm{ml}$ in 15 of 18 boys (6-20 years old) and in 10 of 11 girls (6-19 years old) with documented absence of human growth hormone [35]. In two males, 14.5 and 16 years of age, with $\mathrm{LH}$ concentrations of 0.53 and $0.35 \mathrm{ng} / \mathrm{ml}$, respectively, and in a 17 -year-old girl with an LH level of $1.0 \mathrm{ng} / \mathrm{ml}$, sexual maturation occurred. In another subject, $S A$, a 16 -year-old clinically prepubertal boy with hypopituitarism secondary to removal of a craniopharyngioma, LH levels persistently higher than those recorded in our normal male population were observed. This patient will be discussed in greater detail later in the presentation.

Gonadal dysgenesis. It will be noted in table III that plasma $\mathrm{LH}$ concentrations were 1.2 and $1.45 \mathrm{ng} / \mathrm{ml}$ in two of three girls less than 4 years of age with $\mathrm{XO}$

Table IIr. Plasma concentrations of luteinizing hormone in subjects with gonadal dysgenesis

\begin{tabular}{lccl}
\hline Patient & Age, yr & $\begin{array}{c}\text { Luteiniz- } \\
\text { ing hor- } \\
\text { mone, } \\
\mathrm{ng} / \mathrm{ml}\end{array}$ & $\begin{array}{c}\text { Sex } \\
\text { chromosome } \\
\text { constitution }\end{array}$ \\
\hline$L S$ & $3 \mathrm{wk}$ & 1.2 & $\mathrm{XO}$ \\
$D R$ & 3 & 1.45 & $\mathrm{XO}$ \\
$M B$ & 4 & $<0.25$ & $\mathrm{XO}$ \\
$\mathcal{N S}$ & 5 & $<0.25$ & $\mathrm{XO} / \mathrm{XX}$ \\
& & & trisomy 21 \\
$C R$ & 6 & 0.35 & $\mathrm{XO}$ \\
$P M$ & 8 & $<0.25$ & $* * 1$ \\
$V M$ & 10.5 & 0.4 & $\mathrm{XO}$ \\
$S F$ & 10.5 & 0.4 & $\mathrm{XO}$ \\
$D W$ & 11 & 0.33 & $* * 1$ \\
$A B$ & 11 & 0.78 & $\mathrm{XO}$ \\
$S D$ & 11 & 0.4 & $\mathrm{XO} / \mathrm{XY}$ \\
$A P$ & 12 & 2.83 & $\mathrm{XO}$ \\
$D B$ & 13 & $<0.25$ & $\mathrm{XO} / \mathrm{XX}$ \\
$M K$ & 14 & 3.6 & $\mathrm{XO}$ \\
$D S$ & 15.5 & $<0.25$ & $\mathrm{XO}$ \\
$D T$ & 16 & 2.64 & $\mathrm{Xiso \textrm {X }}$ \\
$S M$ & 16.5 & $<0.25$ & $\mathrm{XO}$ \\
$P A$ & 18 & 1.65 & $\mathrm{XO}$ \\
\hline & 18 & &
\end{tabular}

${ }^{1}$ Buccal smear, 100\% chromatin negative. chromosome constitution. Plasma $\mathrm{LH}$ levels ranged between 0.33 and $3.6 \mathrm{ng} / \mathrm{ml}$ in 10 of 15 subjects over 5 years of age. The plasma LH concentration was below detectable limits in two subjects with $\mathrm{XO} / \mathrm{XX}$ sex chromosome mosaicism ( $\mathcal{N S}$ and $D B$ ), in two subjects with $\mathrm{XO}$ sex chromosome constitution ( $D S$ and $S M$ ) and in a subject with a chromatin-negative buccal smear in whom peripheral karyotyping had not been obtained $(P M)$.

Males with abnormal sexual development. Table IV presents data on a group of males with varied abnormalities of sexual development. Of note is the plasma $\mathrm{LH}$ concentration of $1.7 \mathrm{ng} / \mathrm{ml}$ recorded in a 3-monthold male pseudohermaphrodite $(D R)$. Elevated plasma LH levels were also noted in two older males $(E C$ and $G W$ ) with anorchia and in three of five adult males with Klinefelter's syndrome. Testicular biopsy of these

Table IV. Plasma concentrations of luteinizing hormone in males with abnormalities of sexual development

\begin{tabular}{lccc}
\hline $\begin{array}{l}\text { Patients } \\
\text { and }\end{array}$ & $\begin{array}{c}\text { Age, } \\
\text { diagnosis }\end{array}$ & $\begin{array}{c}\text { Luteiniz- } \\
\text { ing hor- } \\
\text { mone, } \\
\text { ng/ml }\end{array}$ & Comment \\
& &
\end{tabular}

\begin{tabular}{|c|c|c|c|}
\hline \multicolumn{4}{|c|}{ Klinefelter's syndrome } \\
\hline $\mathcal{F L}$ & 20 & 2.58 & $\mathrm{XX}$ \\
\hline$E$ & 28 & 0.38 & $X X Y$ \\
\hline$E C$ & 28 & 5.30 & $\mathrm{XXY}$ \\
\hline$F$ & 46 & 4.85 & $\mathrm{XXY}$ \\
\hline$C$ & 47 & 1.05 & XXY \\
\hline
\end{tabular}

XYY sex chromosome constitution

$\begin{array}{llll}B & 18 & 0.50 & \text { Prison inmate } \\ A B & 38 & 1.05 & \text { Prison inmate } \\ A & 62 & 0.75 & \text { Prison inmate }\end{array}$

Male pseudohermaphroditism

$\begin{array}{llll}D R & 0.25 & 1.7 & \mathrm{XY} \\ K W & 10.5 & 0.25 & \mathrm{XY}, \text { feminizing testes } \\ S D & 11 & 0.25 & \mathrm{XY}, \text { feminizing testes } \\ \mathcal{J} B & 13 & 1.12 & \mathrm{XO} / \mathrm{XY} \\ G O & 15 & 0.35 & \mathrm{XO} / \mathrm{Xiso} / \mathrm{XY} \text { isoY }\end{array}$

Anorchia

$\begin{array}{llll}M M & 11 & 0.27 & \text { Congenital } \\ \mathcal{J A} & 11.5 & 0.25 & \text { Congenital } \\ S K & 12 & 0.25 & \text { Congenital } \\ W H & 17 & 1.3 & \text { Congenital } \\ E C & 19 & 3.4 & \text { Congenital } \\ G W & 22 & 4.37 & \text { Traumatic }\end{array}$


five adult males was consistent with the diagnosis of Klinefelter's syndrome in these patients (table IV). Three males with XYY sex chromosome constitution [67] had plasma LH concentrations that were within our normal adult range for the male $(0.5-0.9 \mathrm{ng} / \mathrm{ml})$.

Precocious sexual development. The concentrations of LH recorded in seven children with true sexual precocity [49] are shown in table V. Plasma LH levels ranged between 0.38 and $0.88 \mathrm{ng} / \mathrm{ml}$ in five children, but were below detectable levels in two $(K P$ and $\mathcal{F W})$. Plasma $\mathrm{LH}$ concentrations were $<0.25 \mathrm{ng} / \mathrm{ml}$ in 13 of 15 girls with precocious thelarche [49] less than 8 years of age. Levels of 0.28 and $0.35 \mathrm{ng} / \mathrm{ml}$ were recorded in two such subjects, 1.6 and 4.5 years of age, respectively. These children were considered to have precocious thelarche rather than true sexual precocity because
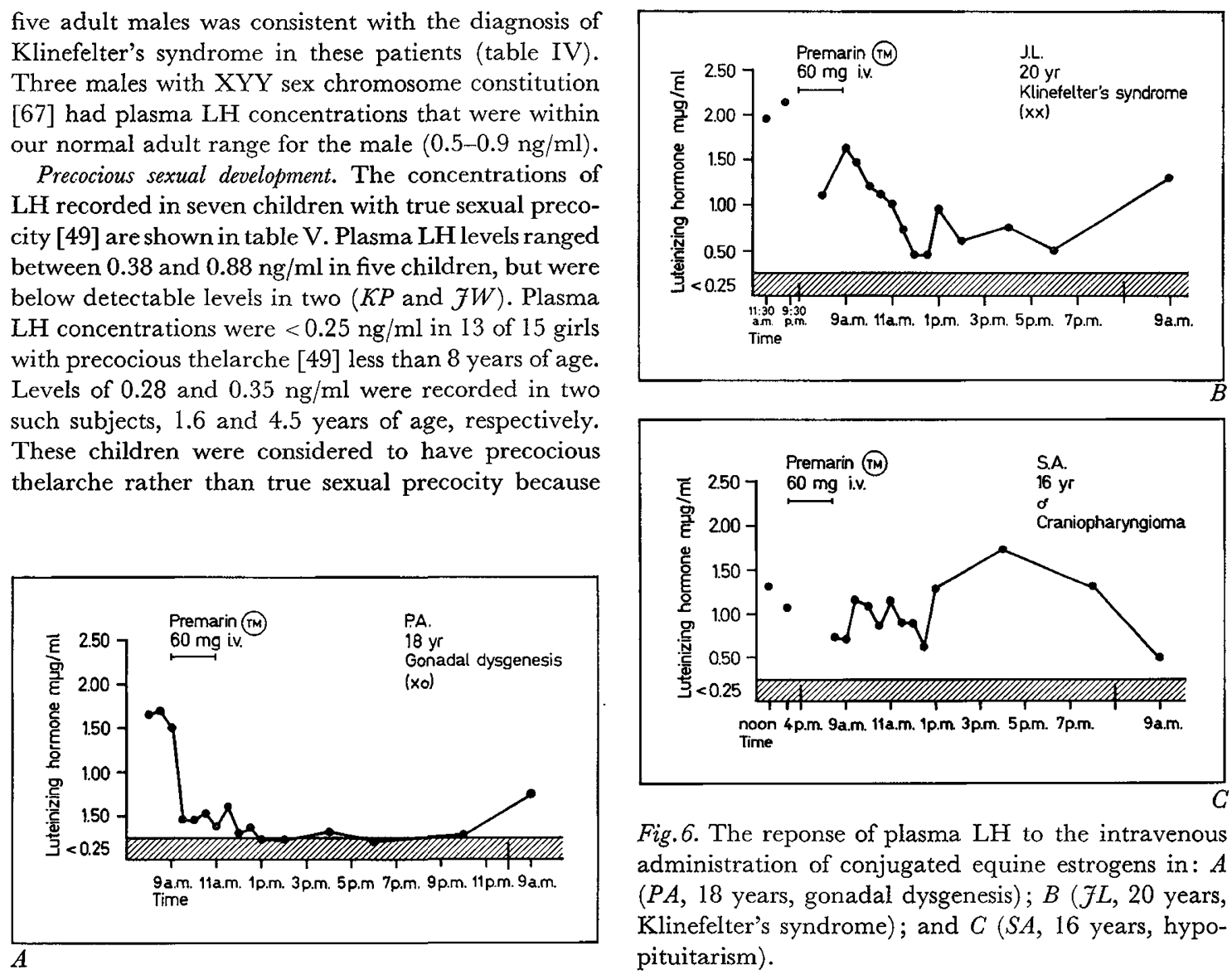

Fig.6. The reponse of plasma $\mathrm{LH}$ to the intravenous administration of conjugated equine estrogens in: $A$ ( $P A, 18$ years, gonadal dysgenesis); $B(\mathcal{J} L, 20$ years, Klinefelter's syndrome); and $C(S A, 16$ years, hypopituitarism).

Table V. Plasma concentrations of luteinizing hormone in patients with true sexual precocity

\begin{tabular}{cccccl}
\hline Patient & $\begin{array}{c}\text { Chronologic } \\
\text { age, } \\
\text { yr }\end{array}$ & $\begin{array}{c}\text { Height } \\
\text { age, } \\
\mathrm{yr}^{1}\end{array}$ & $\begin{array}{c}\text { Bone } \\
\text { age, } \\
\mathrm{yr}^{1}\end{array}$ & $\begin{array}{c}\text { Luteinizing } \\
\text { hormone } \\
\mathrm{ng} / \mathrm{ml}\end{array}$ & \multicolumn{1}{c}{ Comments } \\
\hline Females & 4 & 5.5 & 10 & 0.38 & Idiopathic \\
$L B$ & 6 & 9.5 & 11 & 0.4 & Posttuberculous meningitis \\
$B S$ & 6 & 7 & 11 & $<0.25$ & Idiopathic; medroxyprogesterone acetate \\
$K P$ & 7 & 8.5 & 11.5 & $<0.25$ & Idiopathic; medroxyprogesterone acetate \\
$\mathcal{F W}$ & 7 & 11.5 & 13 & 0.53 & Idiopathic; medroxyprogesterone acetate \\
$M B$ & & & & & \\
Males & 4 & 2.5 & 6.5 & 0.88 & Poststreptococcal meningitis \\
$\mathcal{F S}$ & 11 & 11 & 13 & 0.45 & Ciyst of the cavum velum interpositum \\
$T D$ & & & & & \\
\hline
\end{tabular}

${ }^{1}$ From reference [49]. 
skeletal maturation was consistent with chronologic age, vaginal cytology revealed no evidence of estrogen effect, and there was no progression of sexual development during prolonged periods of observation. Levels of $\mathrm{LH}$ were below the limits of sensitivity of the assay in all of 10 children with premature pubarche [49].
Special Studies

The intravenous infusion of conjugated equine estrogens was followed by a prompt decline in plasma $\mathrm{LH}$ concentrations in patients with gonadal dysgenesis $(P A)$ and Klinefelter's syndrome $(\mathcal{F} L$ ) (fig. $6 A, B)$. When conjugated equine estrogens were administered

Table VI. Radioimmunoassayable luteinizing hormone concentrations in plasma of normal subjects as reported by other authors

\begin{tabular}{|c|c|c|c|c|c|}
\hline \multirow[t]{2}{*}{ Reference } & \multirow[t]{2}{*}{ No. } & \multirow[t]{2}{*}{ Age, yr } & \multirow[t]{2}{*}{ Sex } & \multicolumn{2}{|c|}{$\begin{array}{l}\text { Luteinizing hormone, } \\
\text { mIU 2nd IRP-HMG/ml }\end{array}$} \\
\hline & & & & Mean & Range \\
\hline \multicolumn{6}{|c|}{ Adult males } \\
\hline Present & 7 & $30-75$ & & 8.8 & $6.9-12.3^{1}$ \\
\hline$(7)$ & 40 & $20-50$ & & 23.0 & $8.0-48.0$ \\
\hline \multirow[t]{2}{*}{ (10) } & 114 & $20-49$ & & 15.2 & $<8.0-47.2$ \\
\hline & 44 & $>50$ & & 27.2 & $<8.0-110.4$ \\
\hline$(15)$ & 35 & 一 & & 10.9 & $6.2-23.0$ \\
\hline (27) & 28 & - & & 14.4 & $6.4-25.6$ \\
\hline (38) & 27 & $20-45$ & & 14.0 & $2.5-31.5$ \\
\hline (41) & 10 & $18-22$ & & 10.5 & - \\
\hline (44) & 16 & 一 & & 9.4 & $1.7-24.1$ \\
\hline \multicolumn{6}{|l|}{ Children } \\
\hline \multirow[t]{6}{*}{ Present } & 26 & $0.2-9$ & $\mathrm{M}$ & 一 & $<3.7-\quad 6.6$ \\
\hline & 21 & $10-12$ & $\mathrm{M}$ & - & $<3.7-\quad 7.2$ \\
\hline & 14 & $14-19$ & $\mathrm{M}$ & 一 & $<3.7-19.9$ \\
\hline & 25 & $0.2-9$ & $F$ & - & $<3.7-\quad 7.1$ \\
\hline & 19 & $10-13$ & $\mathrm{~F}$ & - & $<3.7-14.1$ \\
\hline & 4 & $14-15$ & $\mathrm{~F}$ & - & $3.7-19.9$ \\
\hline$(10)$ & 15 & - & - & 12.8 & $3.2-23.2$ \\
\hline \multirow[t]{6}{*}{ (15) } & 20 & $5-8$ & $\mathrm{M}$ & 3.4 & $2.5-\quad 4.5$ \\
\hline & 10 & $9-10$ & $\mathrm{M}$ & 4.8 & $3.5-7.0$ \\
\hline & 20 & $11-12$ & $\mathrm{M}$ & 6.8 & $4.0-12.0$ \\
\hline & 40 & $13-16$ & $\mathrm{M}$ & 9.2 & $4.0-14.0$ \\
\hline & 77 & $2-9$ & $\mathrm{~F}$ & 2.7 & $1.1-\quad 4.0$ \\
\hline & 39 & $10-12$ & $\mathrm{~F}$ & 4.4 & $1.6-12.0$ \\
\hline (19) & 100 & $<10$ & - & 3.0 & $0.0-\quad 7.0$ \\
\hline \multirow[t]{2}{*}{$(20)$} & 一 & $1-10$ & $\mathrm{M}$ & 2.8 & - \\
\hline & - & $1-10$ & $\mathrm{~F}$ & 2.7 & - \\
\hline$(27)$ & - & $1-8$ & -- & 8.0 & $4.8-12.8$ \\
\hline (38) & 6 & $3-8$ & - & 10.2 & $2.5-15.0$ \\
\hline \multirow[t]{2}{*}{$(40)$} & 61 & $<10$ & $\mathrm{M}$ & 5.0 & - \\
\hline & & & $\mathrm{F}$ & 6.0 & - \\
\hline$(45)$ & 17 & - & - & 6.8 & $1.3-14.9$ \\
\hline \multirow[t]{5}{*}{ (53) } & 34 & $8-10$ & $\mathbf{M}$ & 0.9 & - \\
\hline & 38 & $11-13$ & $\mathrm{M}$ & 2.2 & - \\
\hline & 21 & $14-15$ & $\mathbf{M}$ & 4.1 & - \\
\hline & 28 & $8-10$ & $\mathrm{~F}$ & 2.3 & - \\
\hline & 26 & $11-13$ & $\mathrm{~F}$ & 5.5 & - \\
\hline
\end{tabular}

${ }^{1}$ Data are expressed utilizing the directly reported data or conversion factors suggested by the authors. 


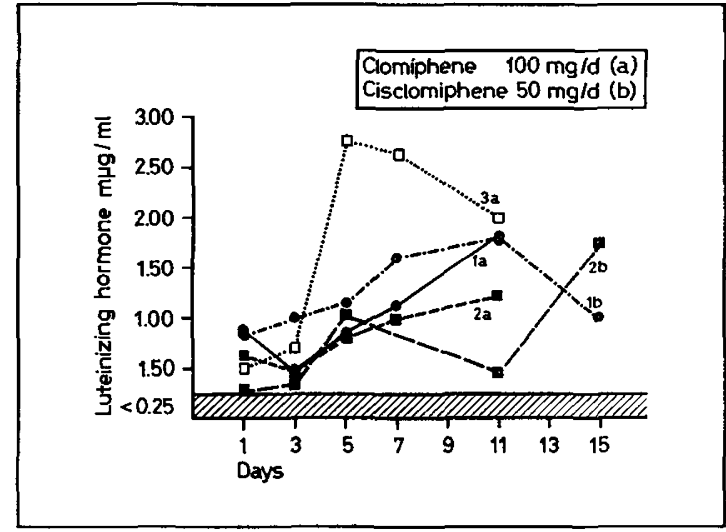

A

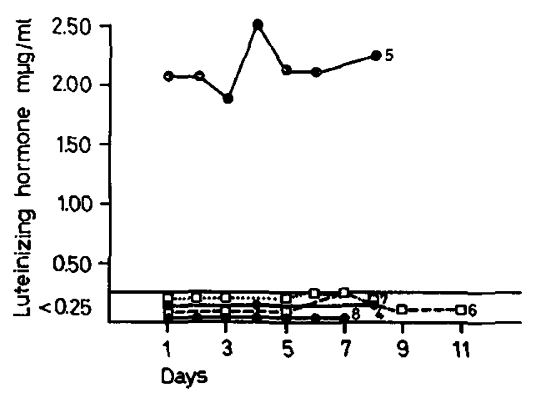

$B$

Fig. 7 A. The response of $\mathrm{LH}$ plasma to orally administered clomiphene citrate (a) and cisclomiphene citrate (b) in normal adult males: 1 ( $\mathcal{N F}, 28$ years); 2 ( $H S, 28$ years); and 3 (WS, 30 years).

$B$. The response of plasma LH to cisclomiphene citrate in males with hypopituitarism: $4(\mathcal{F} M, 15$ years, chromophobe, 1-7 days); 5 ( $S A, 16$ years, craniopharyn., 1-7 days); 6 ( $R S, 20$ years, idiopathic, 1-10 days) ; 7 ( $D G, 16$ years, chromophobe, $1-7$ days); and 8 (TS, 20 years, idiopathic, 1-6 days).

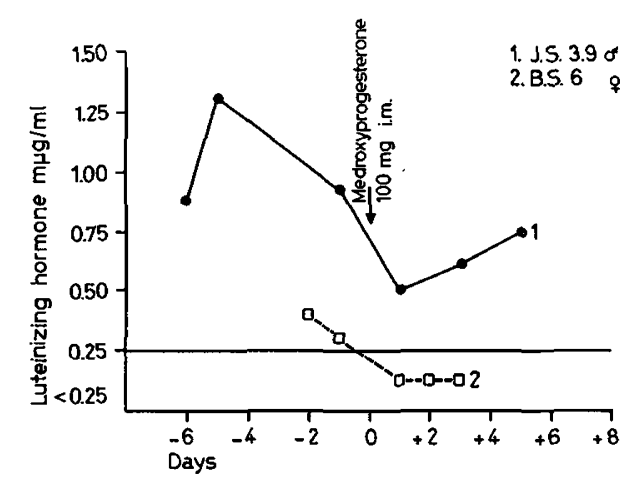

intravenously to $S A$, the subject with hypopituitarism secondary to a craniopharyngioma, the plasma LH response was erratic, but no significant suppression of plasma LH levels was noted (fig. $6 C$ ).

Figure $7 A$ depicts the plasma $L H$ response to the oral administration of clomiphene citrate and cisclomiphene citrate in normal adult males, while figure $7 B$ presents the plasma LH response to orally administered cisclomiphene citrate in five boys with hypopituitarism. It will be noted that plasma $\mathrm{LH}$ concentrations increased promptly in response to both drugs in normal adult males, but there was no significant effect upon plasma $L H$ levels in somewhat younger subjects with hypopituitarism. Subject $S A$ again presented elevated levels of LH which did not change greatly during the administration of cisclomiphene citrate.

The intramuscular administration of medroxyprogesterone acetate was followed by a decline in plasma LH concentrations in two patients with true sexual precocity (fig. 8).

\section{Discussion}

The radioimmunoassay for luteinizing hormone ( $\mathrm{LH})$ reported in this communication is sensitive, reproducible, and apparently specific for materials with luteinizing properties. The lower limit of sensitivity of the assay was $0.25 \mathrm{ng}$ of Hartree pituitary $\mathrm{LH} / \mathrm{ml}$ of undiluted plasma (3.7 mIU of 2nd IRP-HMG/ml) and is comparable to the assay sensitivites reported by Midgley and JAfFe [24] and Yen et al. [52]. The intraassay variability was $10 \%$, while the interassay variability was approximately $7 \%$. Specificity of the antiHCG serum employed in the assay was demonstrated by failure of several other polypeptide hormones to interfere with the anti-HCG:LH-131I reaction, and by the correlation between $\mathrm{LH}$ levels determined by bioassay and by radioimmunoassay of several urinary gonadotropin preparations with widely varying FSHLH contents.

The cross-sectional survey of plasma LH levels revealed that in the majority of prepubertal subjects, LH concentrations were below the lower limits of sensitivity of the assay. The plasma LH level tended to increase with advancing age and stage of sexual maturation. In several subjects with early sexual development, however, LH was not measurable. Table VI compares our data with those of other investigators, several of whom [10,27, 39, 45] have reported higher plasma LH concentrations in children than observed

Fig. 8 . The response of plasma $\mathrm{LH}$ to the intramuscular administration of $100 \mathrm{mg}$ of medroxyprogesterone acetate in subjects with true sexual precocity. 
here. It is difficult to analyze some of these data inasmuch as the numbers of subjects studied by each group have been small and little information concerning age and stage of sexual maturation has been presented. JoHANSON et al. [15], KeNNy et al. [19], LeE et al. [20], and YEN $e t$ al. [53] have reported the presence of immunoreactive $\mathrm{LH}$ in the plasma of most normal prepubertal children; the levels reported, however, were below the lower limit of sensitivity of the method reported here in the majority of instances. Exceedingly wide ranges of plasma $\mathrm{LH}$ concentrations were found in older children. JoHANSON et al. [15] demonstrated a significant correlation between stage of sexual maturation and the plasma $\mathrm{LH}$ concentration for both sexes. These investigators [15] employed a nonequilibrium radioimmunoassay together with larger quantities of plasma $(0.2,0.3 \mathrm{ml})$ than used here $(0.1 \mathrm{ml})$. When it was attempted to increase the volume of plasma in our system, it became impossible to maintain acceptable standards of precision. The reason for this was not apparent. Within the limits of sensitivity of the assay our data are compatible with those of Joranson et al. [15]. KENNY et al. [19], LeE et al. [20, and YEN et al. [53].

It was of interest to observe that several youngsters with abnormalities of gonadal structure or function (gonadal dysgenesis, male pseudohermaphroditism) had relatively elevated plasma $\mathrm{LH}$ concentrations. In subject $L S$, the $\mathrm{LH}$ concentration of $1.2 \mathrm{ng} / \mathrm{ml}$ at 3 weeks of age is unlikely to represent residual placental HCG inasmuch as this material should have been eliminated by this time [25, 52]. GuYda et al. [13] have also reported recently a significant increase in the mean plasma LH concentration of prepubertal children with gonadal dysgenesis. The finding of high $\mathrm{LH}$ concentrations in the plasma of some children with abnormal gonadal development or function suggests that in the prepubertal human the pituitary-gonadal axis is dynamically active. Evidence that supports this hypothesis includes: recent detection of both FSH and $\mathrm{LH}$ in the urine of prepubertal children [2,30,32], and reports of elevated urinary gonadotropin excretion in prepubertal children with gonadal dysgenesis [17]. Furthermore, there is an increase in the circulating gonadotropin level of the prepubertal animal following castration $[9,26,51]$.

The secretion of $\mathrm{LH}$ is regulated in part by the hypothalamic luteinizing hormone-releasing factor [22]. Estrogens and androgens are thought to inhibit the release of LH through an effect on hypothalamic receptors [22]. If the hypothalamic-pituitary-gonadal axis functions in the prepubertal human, then puberty represents an increase in the activity of this system rather than de novo initiation of function. The mechanisms responsible for pubertal changes in the activity of the system remain unknown. DONOvan and VAN DER
WERFF TEN Bosch [9] proposed that pubertal activity of the hypothalamic-pituitary-gonadal axis ensued when 'maturational' changes in the central nervous system decreased the sensitivity of the hypothalamic receptors to the inhibiting effects of gonadal secretions. The nature of these changes has not been clarified but they may involve cellular alterations, or the removal of extrahypothalamic inhibitory influences (pineal [9], amygdala [8]).

Slightly elevated plasma LH concentrations were noted in five of seven children with true, complete sexual precocity, but not in subjects with premature thelarche or precocious pubarche. In the former subjects, inordinately premature 'maturation' of the hypothalamic-pituitary-gonadal axis has apparently occurred, while the latter conditions may represent local tissue responses to unknown stimuli. GUYDA et al. [13] and KENNY et al. [15] have also noted elevated plasma LH levels in subjects with sexual precocity. Although KenNy et al. [18] suggested that plasma LH levels may be slightly increased in females with premature thelarche, neither the data of GuYDA et al. [13] nor the present data substantiate this impression. In two patients with sexual precocity, a progestogen depressed plasma LH levels acutely, implying that inhibitory hypothalamic receptors remained intact. RIFKIND et al. [31] have reported that excretion of $\mathrm{LH}$ and FSH in urine decreased in two of five children with sexual precocity following the administration of medroxyprogesterone acetate.

The 16-year-old male with hypopituitarism, $S A$, is of interest because he had persistently high concentrations of plasma LH. There was no significant plasma LH response to either thesuppressive effects of estrogens or to the stimulating effects of cisclomiphene citrate, suggesting the presence of autonomous LH-secreting cells. Despite these high plasma $L H$ levels, $S A$ remained clinically prepubertal. This may have been due to 1) lack of FSH secretion, a necessary synergistic stimulus to testicular maturation $[16,36]$; or 2) absence of biological activity in an immunologically reactive $\mathrm{LH}$ molecule. Although the first explanation appears most plausible, direct measurements of plasma FSH concentrations will be necessary to confirm this hypothesis.

The advantages of the radioimmunoassay for the measurement of gonadotropins in plasma include: (immunologic) specificity, sensitivity, reproducibility and precision, relative technical simplicity, and the employment of small sample volumes, thus permitting repetitive sampling of the same subject. The utilization of these techniques, together with the competitive protein-binding assays for gonadal secretions [21, 37], will permit longitudinal studies to correlate pituitary and gonadal function with somatic and sexual maturation. 
Summary

The plasma concentration of radioimmunoassayable luteinizing hormone was determined in 243 infants, children, and adolescents. In normal subjects, plasma $\mathrm{LH}$ levels tended to increase with age and stage of sexual maturation, but there was wide individual variation. In several children with abnormal gonadal function or structure (gonadal dysgenesis, male pseudohermaphroditism), plasma LH levels were quite high. Luteinizing hormone was measurable in the plasma of five of seven subjects with true sexual precocity, but was not detectable in most subjects with precocious thelarche or premature pubarche. In a 16-year-old male with hypopituitarism secondary to a craniopharyngioma, persistently elevated plasma LH concentrations were recorded. Estrogens did not suppress nor did cisclomiphene citrate significantly increase these levels, suggesting the presence of autonomous LH-secreting cells.

The results of the present study, and those of other investigators, tend to support the suggestion that the hypothalamic-pituitary axis may be sensitive to altered gonadal function in the prepubertal child. In the normal subject, puberty may occur when the equilibrium established between the hypothalamus, pituitary, and gonads is altered by decreasing sensitivity to gonadal secretions.

\section{References and Notes}

1. August, G.P.; Grumbach, M.M. and Kaplan, S.L.: Correlation of plasma testosterone, LH, $\mathrm{FSH}$, testicular size and bone age with male pubertal development. (Abstract) Society for Pediatric Research, Atlantic City, N.J., May 2, 3 1969, p. 175.

2. Baghdassarian, A.; Guyda, H.; Johanson, A. and Blizzard, R.M.: The excretion of urinary luteinizing hormone $(\mathrm{LH})$ in relation to adolescent development. (Abstract) Society for Pediatric Research, Atlantic City, N.J., May 2, 3, 1969, p. 176.

3. Bagshawe, K.D.; Wilde, G.E. and OrR, A.H.: Radioimmunoassay for human chorionic gonadotrophin and luteinizing hormone. Lancet $i: 1118$ (1966).

4. Berson, S.A.; Yalow, R.S.; Aurbach, G.D. and Potrs, J.T., Jr.: Immunoassay of bovine and human parathyroid hormone. Proc. Nat. Acad. Sci., Wash. 49: 613 (1963).

5. Berson, S.A.; Yalow, R.S.; Glick, S.M. and Roth, J.: Immunoassay of protein and polypeptide hormones. Metabolism 13: 1135 (1964).

6. Butr, W.R.: The immunological assay of human gonadotropins with special reference to specificity; in: F. Polvani and P. Grosignani: Immunological properties of protein hormones, p.57 (Academic Press, New York 1966).

7. Catt, K.J.; Niall, H.D.; Tregaer, G.W. and Burger, H.G.: Disc solid-phase radioimmunoassay of human luteinizing hormone. J. clin. Endocrin. 28: 121 (1968).

8. Critchlow, V. and Bar-Sela, M. E.: Control of the onset of puberty; in: L.MARTINi and W.F. GANONG: Neuroendocrinology, vol.2, p. 101 (Academic Press, New York 1967).

9. Donovan, B.T. and Van Der Werff ten Bosch, J.J.: Physiology of puberty (Williams and Wilkins, Baltimore 1965).

10. FaIman, G. and Ryan, R.J.: Radioimmunoassay for human luteinizing hormone. Proc. Soc.exp. Biol., N.Y. 125: 1130 (1967).

11. Franchimont, P.: Dosage radio-immunologique des hormones luteinisantes chorionique et hypophysaire. Ann. Endocrin., Paris 27: 273 (1966).

12. Greenwood, F. C. ; Hunter, W.M. and Glover, J.S.: The preparation of ${ }^{131}$ I-labelled human growth hormone of high specific radioactivity. Biochem.J. 89: 114 (1963).

13. Guxda, H.; Jorranson, A. and Blizzard, R.: Serum LH in abnormal sexual development. (Abstract) Glin. Res. 17: 285 (1969).

14. Hartree, A.S.: Separation and partial purification of the protein hormones from human pituitary glands. Biochem. J. 100: 754 (1966).

15. Johanson, A.J.; Guyda, H.; Light, C.; Migeon, G.J. and Blizzard, R.M.: Serum luteinizing hormone by radioimmunoassay in normal children. J. Pediat. 74: 416 (1969).

16. Johnson, S.G.: in: E.T.Bell and J.A. Loratne: Recent research on gonadotrophic hormones, chapt. 5, p. 292 (Lvingstone, Edinburgh 1967).

17. KAPLAN, S.A.: Hypopituitarism; in: L.I. GARDner: Endocrine and genetic diseases of childhood, p. 98 (Saunders, Philadelphia 1969).

18. Kenny, F.M.; Mrdgley, A.R. and JAffe, R.B.: Radioimmunoassay of follicle stimulating hormone (FSH) and luteinizing hormone (LH) in sexual precocity, premature thelarche and premature adrenarche. (Abstract) American Pediatric Society, Atlantic City, N.J., Apr.30-May 3, 1969, p. 66.

19. Kenny, F.M.; Mrdgley, A.R., Jr.; Jaffe, R. B.; Garces, L.Y. and VasQueZ, A.: Radioimmunoassay of luteinizing hormone (LH) and follicle stimulating hormone (FSH) in normal children and various abnormal conditions. (Abstract) $\mathrm{J}$. Pediat. 72: 565 (1968).

20. Lee, P.A.; Midglex, A.R. and Jaffe, R.B.: 
Radioimmunoassay of follicle stimulating hormone and luteinizing hormone in normal children. (Abstract) Society for Pediatric Research, Atlantic City, N.J., May 2, 3, 1969, p. 175.

21. MAYes, D. and Nugent, C.A.: Determination of plasma testosterone by the use of competitive protein binding. J.clin. Endocrin. 28: 1169 (1968).

22. MaCann, S. M.; Dhariwal, A.P.S. and Porter, J.C.: Regulation of the adenohypophysis. Ann. Rev. Physiol. 30: 589 (1968).

23. Midgley, A.R., Jr.: Radioimmunoassay: A method for human chorionic gonadotropin and human luteinizing hormone. Endocrinology 79: 10 (1966).

24. Mrdglex, A.R., Jr. and Jaffe, R.B.: Regulation of human gonadotropins. IV. Correlation of serum concentrations of follicle stimulating and luteinizing hormones during the menstrual cycle. J.clin. Endocrin. 28: 1699 (1968).

25. Midgley, A.R., Jr. and JAfFe, R.B.: Regulation of human gonadotropins. II. Disappearance of human chorionic gonadotropin following delivery. J.clin. Endocrin. 28: 1712 (1968).

26. Odell, W.D. and Kiddy, G.A.: Prepubertal gonadal-pituitary luteinizing hormone (LH) interrelations. (Abstract) Clin. Res. 17: 145 (1969).

27. Odel., W.D.; Ross, G.T. and RAYFord, P.L.: Radioimmunoassay for luteinizing hormone in human plasma or serum: Physiological studies. J. clin. Invest. 46: 248 (1967).

28. Odell, W.D.; Wilber, J.F. and Paul, W.E.: Radioimmunoassay of human thyrotropin in serum. Metabolism 14: 465 (1965).

29. PAuL, W. E. and Ross, G.T.: Immunologic crossreaction between human chorionic gonadotropin and human pituitary gonadotropin. Endocrinology 75: 352 (1964).

30. RaIti, S. and Blizzard, R.M.: Measurement of immunologically reactive follicle stimulating hormone in human urine by radioimmunoassay. $\mathrm{J}$. clin. Endocrin. 28: 1719 (1968).

31. Rifkind, A.B.; Kulin, H.E.; Cargille, G.M.; RAYFord, P.C. and Ross, G.T.: Suppression of urinary excretion of luteinizing hormone $(\mathrm{LH})$ and follicle stimulating hormone (FSH) by medroxyprogesterone acetate. J.clin.Endocrin. 29: 506 (1969).

32. Rifkind, A.B.; Kulin, H.E. and Ross, G.T.: Follicle stimulating hormone (FSH) and luteinizing hormone $(\mathrm{LH})$ in the urine of prepubertal children. J.clin. Invest. 46: 1925 (1967).

33. Root, A.W.; Bongrovann, A.M. and Eberlein, W.R.: A testicular-interstitial-cell-stimulating gonadotrophin in a child with hepatoblastoma and sexual precocity. J. clin. Endocrin. 28: 1317 (1968).

34. Root, A.W.; Moshang, T., Jr.; Bongrovanni,
A.M. and Eberlein, W.R.: The relationship of plasma luteinizing hormone concentration to gonadal function. (Abstract) Pediat.Res. 2: 309 (1968).

35. Root, A.W.; Rosenfield, R.L.; Bongiovanni, A.M. and EBerLein, W.R.: The plasma growth hormone response to insulin-induced hypoglycemia in children with retardation of growth. Pediatrics 39: 844 (1967).

36. Rosemberg, E.; Mancini, R.E.; Grigler, J.F. and Bergada, C.: Effect of human menopausal gonadotropin on prepuberal testes; in: E. RosemBERG: Gonadotropins 1968, p. 527 (Geron-X, Los Altos, Calif. 1968).

37. Rudd, B.T.; ROSENFIELD, R.L.; BongIOVANNI, A.M. and EberLein, W.R.: The measurement of urinary testosterone glucuronide by competitive protein binding and validation by a double isotope derivative assay. Steroids 13: 227 (1969).

38. Ryan, R.J. and Faiman, C.: Radioimmunoassay of FSH and LH in human serum: The effects of age and infusion of several polyamines in males; in: E. Rosemberg: Gonadotropins 1968, p. 333 (Geron-X, Los Altos, Galif. 1968).

39. Saxena, B.B.; Demura, H.; Gandy, H.M. and Peterson, R.E.: Radioimmunoassay of human follicle stimulating and luteinizing hormones in plasma. J.clin. Endocrin. 28: 519 (1968).

40. SchalGh, D.S. and BRYSON, M.F.: Plasma luteinizing hormone levels in normal children and in subjects with pituitary and gonadal dysfunction: Determination by radioimmunoassay. (Abstract) Pediat. Res. 1: 308 (1967).

41. Schalgh, D.S.; Parlow, A.F.; Boon, R. G. and Reichlin, S.: Measurement of human luteinizing hormone in plasma by radioimmunoassay. $\mathrm{J}$. clin. Invest. 47: 665 (1968).

42. Sobrevilla, L.A. and Mrdgley, A.R.: Plasma luteinizing hormone levels in males acutely exposed to high altitudes; in: E. RosemberG: Gonadotropins 1968, p. 367 (Geron-X, Los Altos, Calif. 1968).

43. Swerdloff, R. S. and Odell, W. D.: Some aspects of the control of secretion in LH and FSH in humans; in: E.RosemberG: Gonadotropins 1968, p. 155 (Geron-X, Los Altos, Calif. 1968).

44. TAnner, J.M.: Growth at adolescence; 2nd ed. (Blackwell, Oxford 1962).

45. Taymor, M.L.; Aona, T. and Pheteplace, C.: Serum levels of FSH and $\mathrm{LH}$ by radioimmunoassay; in: E. RosemberG: Gonadotropins 1968, p. 349 (Geron-X, Los Altos, Calif. 1968).

46. Thomas, $\mathrm{K}$. and Ferin, J.: A new rapid radioimmunoassay for HCG (LH, ICSH) in plasma using dioxan. J.clin. Endocrin. 28: 1667 (1968). 
47. Utiger, R.D.; Parker, M.L. and Daughaday, W.H.: Studies on human growth hormone. I. A radioimmunoassay for human growth hormone. J.clin. Invest. 4: 254 (1962).

48. Wide, L.; Roos, P. and Gemzell, C.: Immunological determination of human pituitary luteinizing hormone (LH). Acta endocrin., Kbh. 37: 445 (1961).

49. Wilkins, L. : The diagnosis and treatment of endocrine disorders in childhood and adolescence; 3rd ed. (Thomas, Springfield 1965).

50. Yalow, R.S. and Berson, S.A.: Immunoassay of endogenous plasma insulin in man. J.clin. Invest. 39: 1174 (1960).

51. Yamamoto, M.; Diebel, N.D. and Bogdanove, E.M.: Radioimmunoassay of early changes in serum LH after castration. (Abstract no. 1365) Fed.Proc. 28: 505 (1969).

52. Yen, S. S. G.; Llerena, O.; Little, B. and Pearson, O.H.: Disappearance rates of endogenous luteinizing hormone and chorionic gonadotropin in man. J. clin. Endocrin. 28: 1763 (1968).

53. Yen, S.S. G. ; Vicic, W.J. and Kearahner, D.V.: Gonadotropin levels in puberty. I. Serum luteinizing hormone. J.clin. Endocrin. 29: 382 (1969).

54. APL, Ayerst Pharmaceutical Company, New York, NY.

55. Difco, Detroit, MI.

56. Provided by Dr. A.S.Hartree, University of Cambridge, England (10-24-64) (14). Biologic potency: 5.7 (3.6-9.2) times NIH-LH-S3; 7.2 (5.6-22.5) times NIH-LH-S6. (Approximately 4.7 times NIH-LH-S1 ; 2,770 IU 2nd IRP-HMG/mg.)

57. Iso-Serve, Cambridge, MA.

58. Provided by Dr. D.R. Bangham, Department of Biological Standards, Medical Research Council, Mill Hill, London, England.

59. Provided by the National Pituitary Agency, Baltimore, MD.
60. Phosphate-buffered saline (PBS), $0.01 \mathrm{M} \mathrm{Na}_{2} \mathrm{HPO}_{4}$ : $\mathrm{NaH}_{2} \mathrm{PO}_{4}-0.15 \mathrm{~m} \mathrm{NaCl}, \mathrm{pH} 7.5$, with $2.5 \mathrm{~g} / 100 \mathrm{ml}$ crystallized bovine serum albumin (Pentex, Inc., Kankakee, IL).

61. Packard Instrument Company, Inc., Downers Grove, IL.

62. Premarin, Ayerst Pharmaceutical Company, New York, NY.

63. Provided by Drs. A.H. MAcgregor and J.E. Johnson, Jr., Wm. S. Merrell Company, Cincinnati, $O$.

64. Provided by Dr. A.E.Wilhermi, Emory University, Atlanta, GA (HS 612B).

65. Mann Laboratories, New York, N.Y.

66. Provided by Dr. M. Root, Lilly Research Laboratories, Indianapolis, IN. (No.818194).

67. Sera provided by Dr. M. Telfer, Elwyn School, Elwyn, PA.

68. All procedures were performed in accordance with the provisions set forth in the Declaration of Helsinki.

79. We thank Mr. R. MARKs for competent technical assistance, Dr. P. FEIGL for statistical assistance, and Mrs. E. MorRIs for unfailing secretarial competence.

70. Supported by Public Health Service Research Grants nos. HD 00379 and T0 1 AM 05197. Portions of these studies were conducted at the Clinical Research Center of the Children's Hospital, supported by Public Health Service Research Grant no. FR 00240. A.W.Root is the recipient of Public Health Service Career Development Award $1 \mathrm{~K} 03 \mathrm{HD} 38338$.

71. Request for reprints should be addressed to: A.W.Root, M.D., Division of Pediatrics, Albert Einstein Medical Center, York and Tabor Roads, Philadelphia, PA 19141 (USA).

72. Accepted for publication October 3, 1969. 